\title{
Determination of heavy metals in water of Ganga and Yamuna river basin in Allahabad
}

\section{SYED SUAIB NAUSHAD, ALOK MILTON LALL AND AMIT ALEXANDER CHARAN}

Article Chronicle :

\section{Received :}

13.06.2014;

Accepted :

30.11.2014
SUMMARY : The objectives of this paper were to illustrate the distribution and levels of sediment contamination by heavy metals in the Allahabad city, and to compare recent data with those collected during the early 2001. The metals as, $\mathrm{Cd}, \mathrm{Ni}, \mathrm{Cu}, \mathrm{Fe}, \mathrm{Pb}, \mathrm{Co}, \mathrm{Ni}$ and $\mathrm{Zn}$ were chosen because of their abundance and toxic effects in the environment of highly industrialized and urbanized areas. The pollutants, which do not remain in water column or solution, could be absorbed rapidly by particulate matters and thereby they also could escape any detection by water monitoring schemes (Meiggs, 1980). Some heavy metals like $\mathrm{Cd}, \mathrm{Cu}, \mathrm{Fe}, \mathrm{Ni}$ and $\mathrm{Pb}$ were determined in water from four reaches of the river from Yamuna (river-km 1112) upstream from Sangam to Arail Ghat (river$\mathrm{km} 851$ ) downstream from Allahabad.

HOW TO CITE THIS ARTIClE : Naushad, Syed Suaib, Lall, Alok Milton and Charan, Amit Alexander (2014). Determination of heavy metals in water of Ganga and Yamuna river basin in Allahabad. Asian J. Environ. Sci., 9(2): 106-108.
Key Words :

Heavy metals, Ganga, Yamuna, River basin
Author for correspondence :

\section{SYED SUAIB}

NAUSHAD

Department of

Biochemistry and

Biochemical

Engineering, Jacob

School of Biotechnology

and Bioengineering,

(SHIATS), ALLAHABAD

(U.P.) INDIA

Email: suaibnaushad@

gmail.com

See end of the article for

Coopted authors' 